\title{
Influence of Oblique Magnetic Field from Duplication Magnet on Magnetic Duplication Characteristics
}

\author{
S. Tomikawa, N. Inaba, T. Komine, R. Sugita, and T. Muranoi \\ Dept. of Media and Telecomm. Eng., Ibaraki University, 4-12-1 Nakanarusawa-cho, Hitachi, Ibaraki 316-8511, Japan
}

The magnetic duplication technique using patterned master media is a promising means of writing servo signals onto hard disks at high speed and low cost. It is expected that the direction of the applied magnetic field in the duplication process significantly influences the duplication characteristics. The objective of this paper is to clarify the influence of the oblique magnetic field out of the master plane. Experiments showed that the reproduced waveform from a slave duplicated with an oblique field is asymmetric near both edges of the protrusion of the master. The asymmetric waveform is improved by increasing the field, but the duplication characteristics with an oblique field are still inferior to those with an in-plane field. Computer simulation of the magnetization distribution of the slave duplicated with an oblique field shows that the distribution is asymmetric near both edges of the protrusion of the master, coinciding with the experimental results.

Key words: oblique magnetic field, duplicating field, servo-writing, hard disk

\section{磁気転写用磁石の斜め方向磁場が転写特性に及ぼす影響}

富川智史，稲葉望，小峰啓史，杉田龍二，村野井徹夫

茨城大学工学部, 茨城県日立市中成沢町 4-12-1（率316-8511）

\section{1. はじめに}

ハードディスクにサーボ信号を高速かつ安価に形成する 方法として, 磁気転写法が注目されている1) 7). 現在, 転写 磁場は電磁石や永久磁石で印加しており，これらはギャッ プ部から磁場が円弧状に発生する ${ }^{6)}$. 磁気転写法においては, 転写磁場はスレーブの膜面内方向に印加することが基本で あるが，このように膜面に対して斜め方向の磁場(以下，斜 め方向磁場と記す)が印加される場合が起こりうる. 実際に 使われている磁石において, 斜め方向磁場は $35^{\circ} \sim 45^{\circ}$ の傾 きを持っている. 従来の研究においては, 転写磁場の理想 的な印加方法であるスレーブの膜面内方向に印加されたと きのみで検討されており, 斜め方向磁場が転写特性に及ぼ す影響についてはまだ明らかになっていない.

本研究では, 斜め方向磁場が，転写特性に及ぼ寸影響について， 実験とコンピュータシミュレーションにより明らかにする.

\section{2. 実験方法及びシミュレーション方法}

実験に用いたマスター媒体は, Si 基板上に膜厚 $1 \mu \mathrm{m}$ の $\mathrm{Fe} 70 \mathrm{Co} 30$ 膜(飽和磁化 $M_{\mathrm{s}}=1900 \mathrm{emu} / \mathrm{cm}^{3}$, 保磁力 $H_{\mathrm{c}} \fallingdotseq$ $70 \mathrm{Oe}$, 透磁率 $\mu=100$ )をストライプ状に形成したもの であり，ストライプパターンの幅及び隣接ストライプの間 隔は $2.5 \mu \mathrm{m}$, ストライプの長さは $6 \mathrm{~mm}$ である4). スレー ブ媒体としては，薄層メタル塗布型テープ(飽和磁化 $M_{\mathrm{s}}=$ $300 \mathrm{emu} / \mathrm{cm}^{3}$, 保磁力 $H_{\mathrm{c}}=2.0 \mathrm{kOe}$, 磁性膜厚 $0.3 \mu \mathrm{m}$ )を用 いた5).転写されたスレーブの再生には, 誘導型磁気へッド である DVC 方式 VTR 用メタル-イン-ギャップ(MIG)ヘッ
ド(ギャップ長 $0.3 \mu \mathrm{m}$, トラック幅 $13 \mu \mathrm{m}$ )を用いた. Fig. 1 に転写方法の概略図を示す。まず，Fig. 1(a)に示されるよ うに, スレーブ膜面に対して水平方向に磁場を印加し初期

(a)

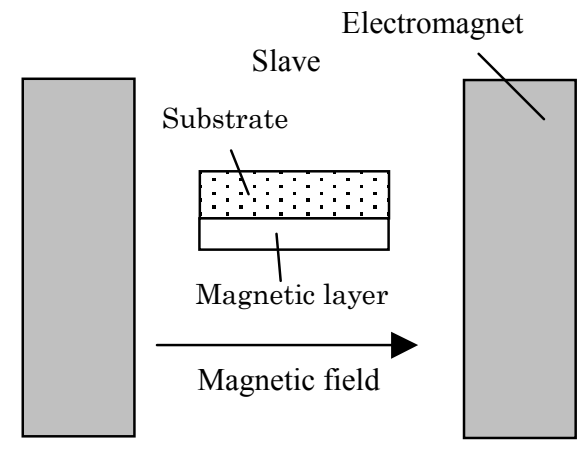

(b)
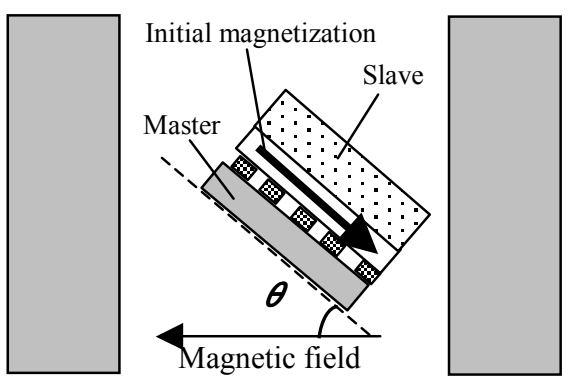

Fig. 1 Schematic diagram of the (a) initial magnetization process and (b) duplication process. 
磁化を行う. 次に Fig. 1(b)に示されるように, 初期磁化さ れたスレーブにマスターを接触させ，転写磁場を膜面と磁 場方向とのなす角を $\theta$ として印加し磁気転写を行った. 転 写されたスレーブをビッター現像法により観察し，ドラム テスタを用いて再生波形を検討した。

また，転写磁場を印加したときのマスター近傍の磁場分 布を有限要素法によって求めた。本計算におけるマスター の飽和磁化 $M_{\mathrm{s}}$, 保磁力 $H_{\mathrm{c}}$, 透磁率 $\mu$ はそれぞれ, 1900 $\mathrm{emu} / \mathrm{cm}^{3}, 0 \mathrm{Oe}, 100$ とした. 計算により求めた磁場分布と, 実験に用いたスレーブの $\mathrm{MH}$ 曲線(飽和磁化 $M_{\mathrm{s}}=300$ $\mathrm{emu} / \mathrm{cm}^{3}$, 保磁力 $H_{\mathrm{c}}=2.0 \mathrm{kOe}$ )から, 転写されたスレーブ の磁化分布を推定した7).

Fig. 2 に本研究で使用した薄層メタル塗布型テープの, 長手方向 $(\mathrm{x}$ 方向)及び膜面に垂直方向( $\mathrm{y}$ 方向)の $\mathrm{MH}$ 曲線を 示す. Fig 2(a) と Fig.2 (b)に示すように, それぞれの角型比 は 0.84 及び 0.2 である. また, 本研究では, 記録ビット長 $L$ を $2.5 \mu \mathrm{m}$, スレーブ膜厚を $0.3 \mu \mathrm{m}$ として実験を行ったの で, 膜厚方向の反磁場が大きく, スレーブは $\mathrm{MH}$ 曲線のよ うに振る舞うと考えられる. 従ってスレーブに記録される 磁化の $\mathrm{y}$ 成分 $M \mathrm{y}$ は x 成分 $M_{\mathrm{x}}$ に比べて小さいと推定され, 第一次近似的に $M_{\mathrm{x}}$ 分布のみを考慮した.
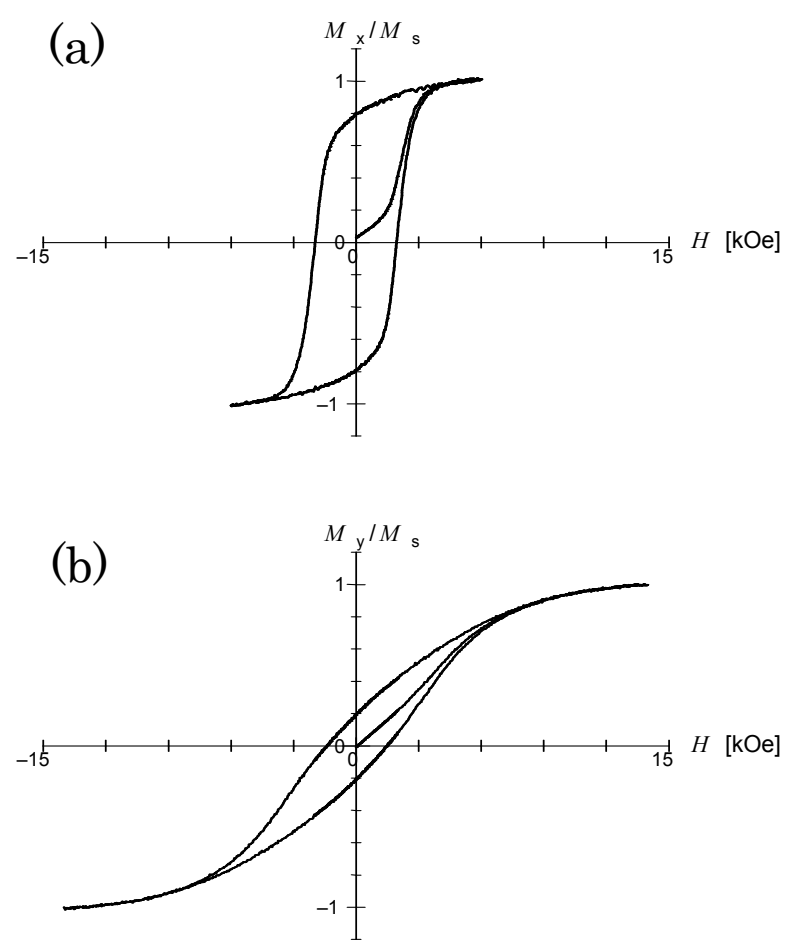

Fig. 2 Hysteresis loops of the slave disk, (a) longitudinal machine direction (b) parpendicular to plane.

\section{3. 実験結果}

\section{1 転写特性の $\theta$ 依存性}

Fig. 3 に, $\theta$ を $0^{\circ}$ 及び $45^{\circ}$, 転写磁場 $H_{\mathrm{a}}$ を $2.0 \mathrm{kOe}$ とし て磁気転写を行ったスレーブのビッター現像写真を示す. 一般に， $H_{\mathrm{a}}$ をスレーブ媒体の保磁力と同等あるいはやや高 い值に設定したときに，最も優れた転写が行われる ${ }^{2} . \theta$ が 0॰のときには, Fig. 3(a)に示されるように, マスター磁性膜 両側エッジに対応する部分にほぼ同量の磁性粒子が付着し ているが, $\theta$ が 450の場合, Fig. 3 (b)に示されるように, マ スター磁性膜両側エッジに対応する部分の磁性粒子付着量 に大きな相違が見られる.

Fig.4 は, $\theta$ を $0^{\circ}$ 及び $45^{\circ}$ として, $2.0 \mathrm{kOe}$ の $H_{\mathrm{a}}$ を印加し て転写を行ったスレーブからの再生波形である。同図にお いて, $\theta$ が $0^{\circ}$ 場合は, 再生波形のプラスピーク $E_{0,+\mathrm{p}}$ とマ イナスピーク $E_{0, \mathrm{p}}$ が同程度であるが, $\theta$ が $45^{\circ}$ では, $E_{0,+\mathrm{p}}$ が $E_{0, \mathrm{p}}$ に比べかなり小さくなっていることがわかる. また， $\theta$ が $0^{\circ}$ 場合にはサブピーク3は見られないが，450ではサブ ピークが現れている.

Fig. 5 に再生出力の $\theta$ 依存性をまとめる. 同図から, $\theta$ が 大きくなるに従い, $E_{0,+\mathrm{p}}$ と $E_{0, \mathrm{p}}$ の差が大きくなっているこ とがわかる．この原因は， $H_{\mathrm{a}}$ を斜め方向に印加すると，マ スター磁性膜両側エッジ近傍の磁場分布が非対称となるこ とにあると考えられる.この非対称磁場により，スレーブ に転写された磁化が, マスター磁性膜両側エッジに対応す る部分で非対称性になっていると推定される.

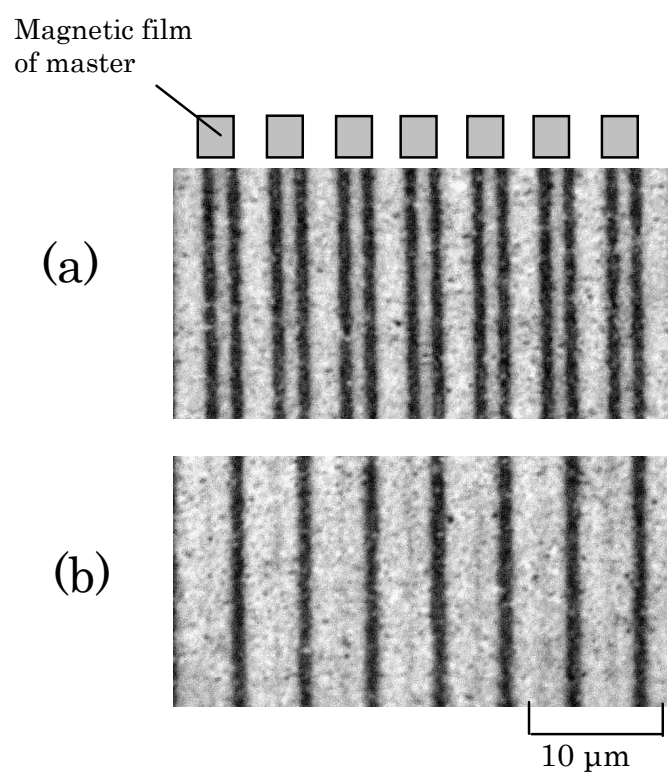

Fig. 3 Bitter patterns of slaves duplicated with $\theta$ values of (a) $0^{\circ}$ and (b) $45^{\circ}$. 


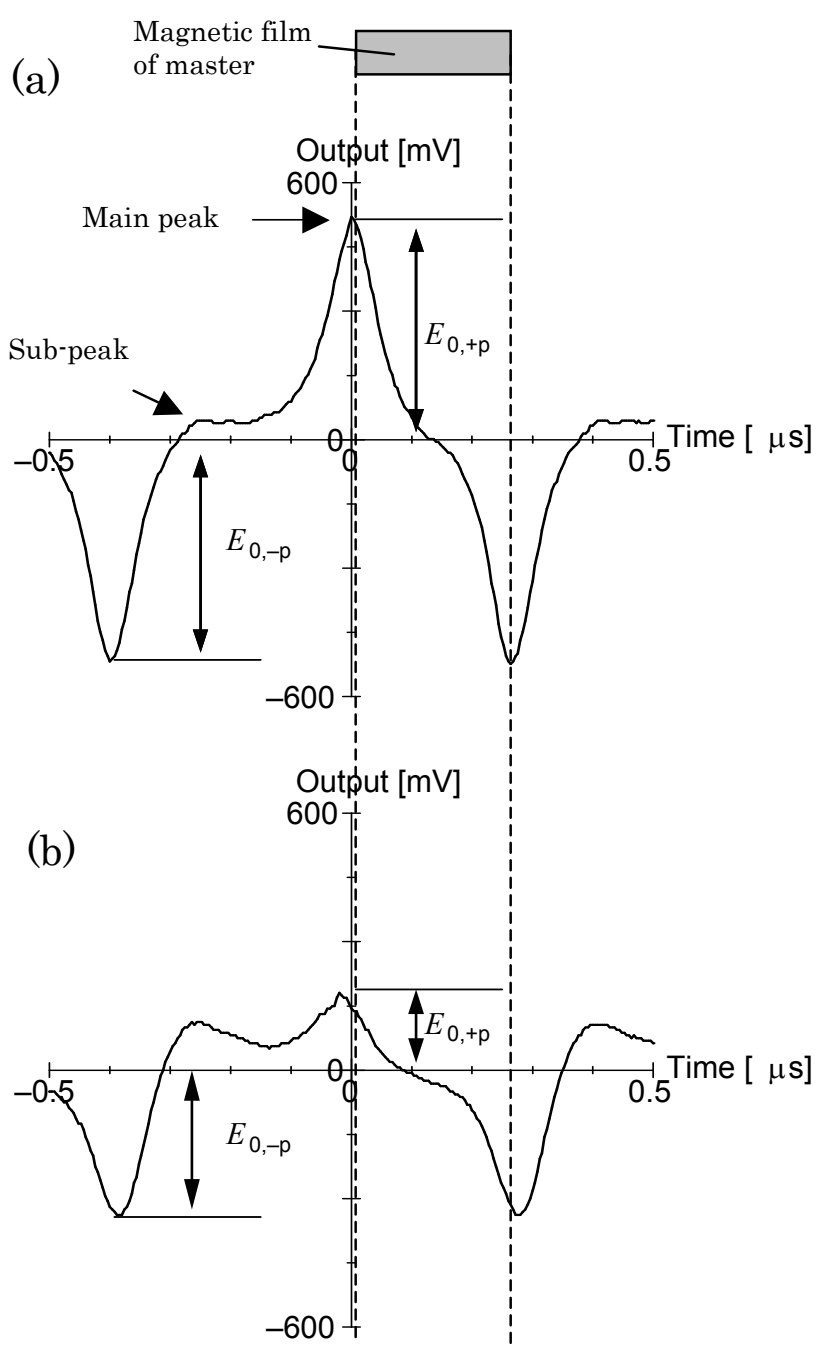

Fig. 4 Reproduced waveforms from slaves duplicated with $\theta$ values of (a) $0^{\circ}$ and (b) $45^{\circ}$.

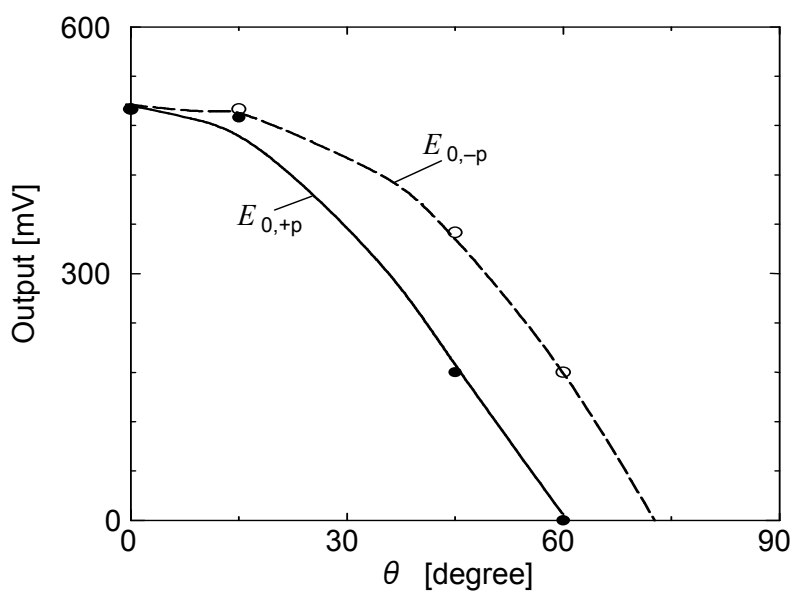

Fig. $5 \theta$ dependence of the signal output from a slave duplicated with an oblique magnetic field. (a)

Magnetic film of master

(b)
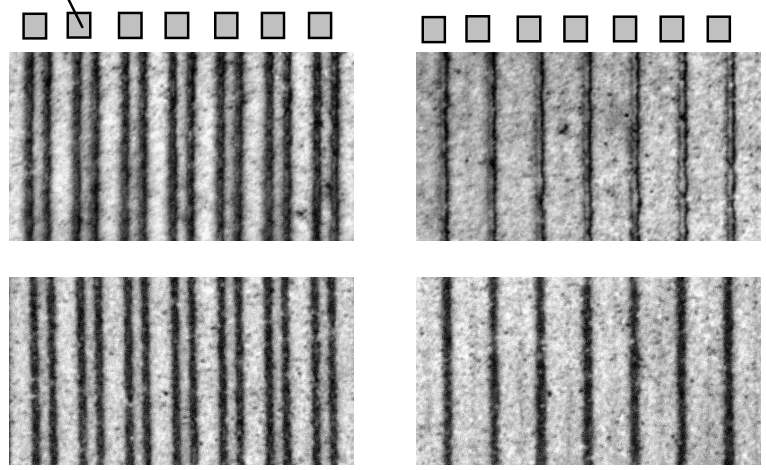

(c)
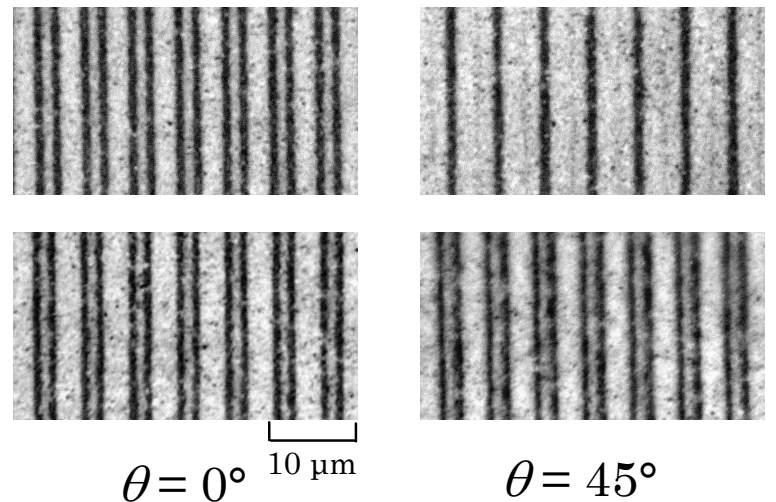

$\theta=45^{\circ}$

Fig. 6 Bitter patterns of slaves duplicated with $H_{\mathrm{a}}$ of (a) $1.6 \mathrm{kOe}$, (b) $2.0 \mathrm{kOe}$ and (c) $2.8 \mathrm{kOe}$, and with $\theta$ values of $0^{\circ}$ and $45^{\circ}$.

\section{2 転写特性の $H_{a}$ 依存性}

Fig. 6 は, $\theta$ を $0^{\circ}$ 及び $45^{\circ}, H_{\mathrm{a}}$ を $1.6 \mathrm{kOe}, 2.0 \mathrm{kOe}, 2.8$ $\mathrm{kOe}$ として転写したスレーブのビッター現像写真である. 同図より, $\theta$ が $0^{\circ}$ のきは磁性粒子付着状態に $H_{a}$ 依存性は ほとんど見られず，マスター磁性膜両側エッジに対応する 部分の付着量は同等である。一方, $\theta$ が $45^{\circ}$ の場合には, $H_{\mathrm{a}}$ を $1.6 \mathrm{kOe}$ 及び $2.0 \mathrm{kOe}$ として転写すると, マスター磁性 膜両側エッジに対応寸る部分の磁性粒子付着量に明らかな 相違が見られるのに対して， $H_{\mathrm{a}}$ を $2.8 \mathrm{kOe}$ とすると，この 相違が見られなくなっている. 寸なわち, マスター磁性膜 両側エッジに対応する部分の磁性粒子付着量の差は, $H_{\mathrm{a}}$ を 強くすることで改善できる.

Fig. 7 は, $\theta$ を $0^{\circ}$ 及び $45^{\circ}$ として, $1.6 \mathrm{kOe}, 2.0 \mathrm{kOe}, 2.8$ $\mathrm{kOe}$ の $H_{\mathrm{a}}$ で転写したスレーブからの再生波形である. Fig. 7 (a)，(b)は，それぞれ $\theta$ が $0^{\circ}$ 及び $45^{\circ}$ の場合である. Fig. 7 (a)に示寸ように, $\theta$ が $0^{\circ}$ では $H_{\mathrm{a}}$ によらず高い再生出力を示 している. $\theta$ が $45^{\circ}$ では Fig. 7 (b)に示されるように, $H_{\mathrm{a}}$ を $2.8 \mathrm{kOe}$ とすると, $2.0 \mathrm{kOe}$ と比べ, 再生出力が大きくなり, $E_{0,+\mathrm{p}}$ と $E_{0, \mathrm{p}}$ の差が少なくなることがわかる. $\theta$ が $45^{\circ}$ の場 合, $H_{\mathrm{a}}$ を $2.8 \mathrm{kOe}$ すると $2.0 \mathrm{kOe}$ と比心転写特性がかなり 改善されるが, $E_{0,+\mathrm{p}}$ と $E_{0, \mathrm{p}}$ との間に差が存在する, 半值幅 が広い,サブピークが見られる等の点から， $\theta$ が $0^{\circ}$ のきの 特性には及ばない。

Fig. 8 に, $\theta$ を $0^{\circ}$ 及び $45^{\circ}$ として転写を行ったスレーブの 再生出力 $E_{0,+\mathrm{p}}, E_{0, \mathrm{p}}$ 及び $E_{\mathrm{p}-\mathrm{p}}$ の $H_{\mathrm{a}}$ 依存性をまとめる. ここ で, $E_{\mathrm{p} \text { p }}$ は $E_{0, \mathrm{p}}$ と $E_{0, \mathrm{p}}$ の和である. Fig. $8(\mathrm{a})$ からわかるよ うに, $\theta$ が $0^{\circ}$ で転写を行った場合には, $1.6 \mathrm{kOe} \sim 2.8 \mathrm{kOe}$ の 
範囲では, $E_{0,+\mathrm{p}}, E_{0, \mathrm{p},} E_{\mathrm{p}-\mathrm{p}}$ がほぼ一定值を示している. 一方, Fig. 8 (b)に示すように, $\theta$ を $45^{\circ}$ として磁気転写を行った場 合には, $H_{\mathrm{a}}$ が小さいときには $E_{0,+\mathrm{p}}$ が $E_{0, \mathrm{p}}$ に比べて小さく なっているが, $H_{\mathrm{a}}$ が強くなるに従い, $E_{0,+\mathrm{p}}$ と $E_{0, \mathrm{p}}$ が増加す ると同時に, 両者の差が小さくなる.また, $H_{\mathrm{a}}$ を $3.2 \mathrm{kOe}$ に設定すると, $E_{0,+\mathrm{p}}$ と $E_{0, \mathrm{p}}$ は同程度となるが, $H_{\mathrm{a}}$ を 2.8 $\mathrm{kOe}$ に設定した場合と比べ $E_{\mathrm{p} \text { - }}$ は減少する. 斜め方向に $2.8 \mathrm{kOe}$ の磁場を印加したとき, 面内方向に印加される磁 場は $2.8 \mathrm{kOe} \times \cos 45^{\circ}=2.0 \mathrm{kOe}$ に相当することから， このことが転写特性の向上に影響を及ぼしたと考えられ る.
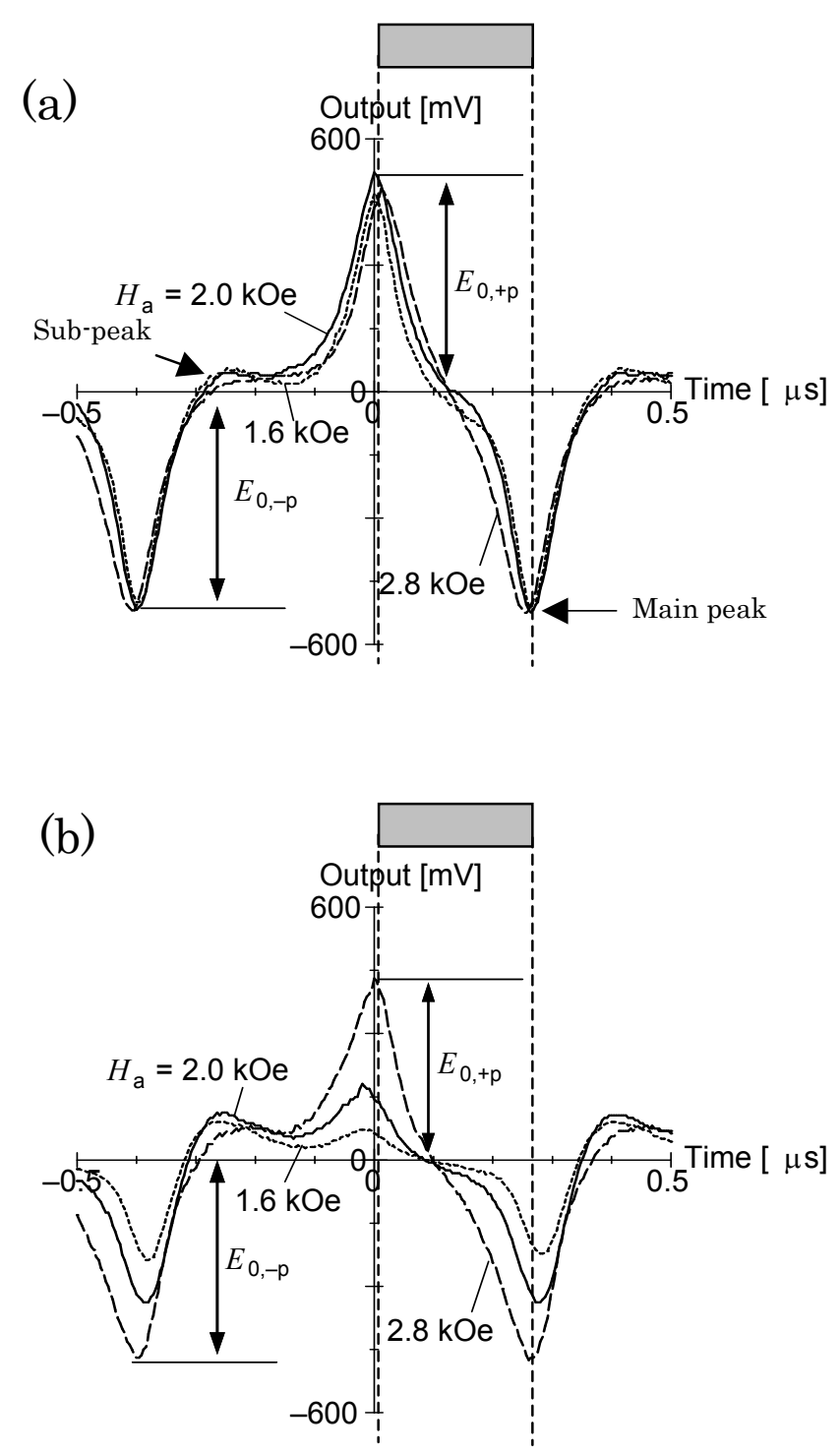

Fig. 7 Reproduced waveforms from slaves duplicated with $H_{\mathrm{a}}$ values of $1.6 \mathrm{kOe}, 2.0 \mathrm{kOe}$ and, $2.8 \mathrm{kOe}$, and with $\theta$ values of (a) $0^{\circ}$ and (b) $45^{\circ}$.

\section{3 シミュレーション結果}

Fig. 9 に, $\theta$ を $0^{\circ}$ 及び $45^{\circ}, H_{\mathrm{a}}$ を $2.0 \mathrm{kOe}$ として磁気転写 を行ったスレーブの磁化分布のシミュレーション結果を示 す. 横軸は位置, 縦軸は $M_{\mathrm{x}} / M_{\mathrm{s}}$ を示している.ここで, $M_{\mathrm{x}}$ は, スレーブの磁化のビット長方向成分, $M_{\mathrm{s}}$ は飽和磁化で ある，同図から， $\theta$ が $0^{\circ}$ では，マスター磁性膜両側エッジに 対応する部分の磁化分布が対称になっているが, $\theta$ が $45^{\circ} の$ 場合は非対称になっていることがわかる.この磁化分布の 非対称性が, $\theta$ を $45^{\circ}$ として転写を行ったスレーブのビッタ 一像及び再生波形の $E_{0,+\mathrm{p},} E_{0, \mathrm{p}}$ がマスター磁性膜両側エッ ジに対応する部分で非対称となる要因であると推定され， ピークの高さについては, Figs. 3, 4 の実験結果と一致す る.

Fig. 10 に, $\theta$ を $45^{\circ}$ とし, $H_{\mathrm{a}}$ を $1.6 \mathrm{kOe}, 2.0 \mathrm{kOe}, 2.8 \mathrm{kOe}$ として磁気転写を行ったスレーブ媒体の, 磁化分布のシミ ュレーション結果を示す. スレーブ媒体の磁化分布は, マ スター媒体磁性膜両側エッジに対応する部分で非対称にな っているが, $2.8 \mathrm{kOe}$ では, その非対称性が緩和されている

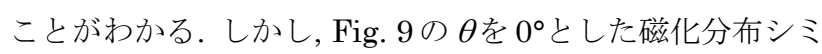
ユレーション結果に比ベ, マスター磁性膜エッジに対応す る部分の磁化変化はなだらかになっている.このことから， 再生出力については転写磁場が強いほど斜め方向磁場の影 響は緩和されるが，水平に印加したときの特性には至らな いことが推定される.この結果はFigs. 6, 7 及び 8 の実験結 果と一致する.
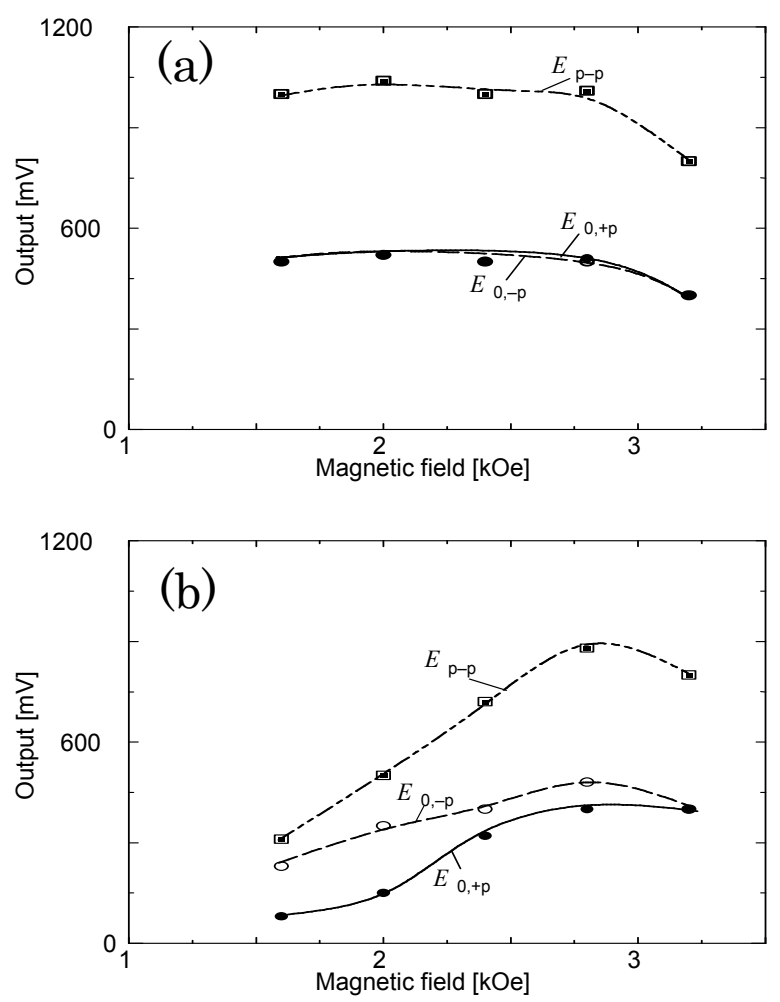

Fig. 8 Duplication field $H_{\mathrm{a}}$ dependence of the signal output from slaves duplicated with $\theta$ values of (a) $0^{\circ}$ and (b) $45^{\circ}$. 


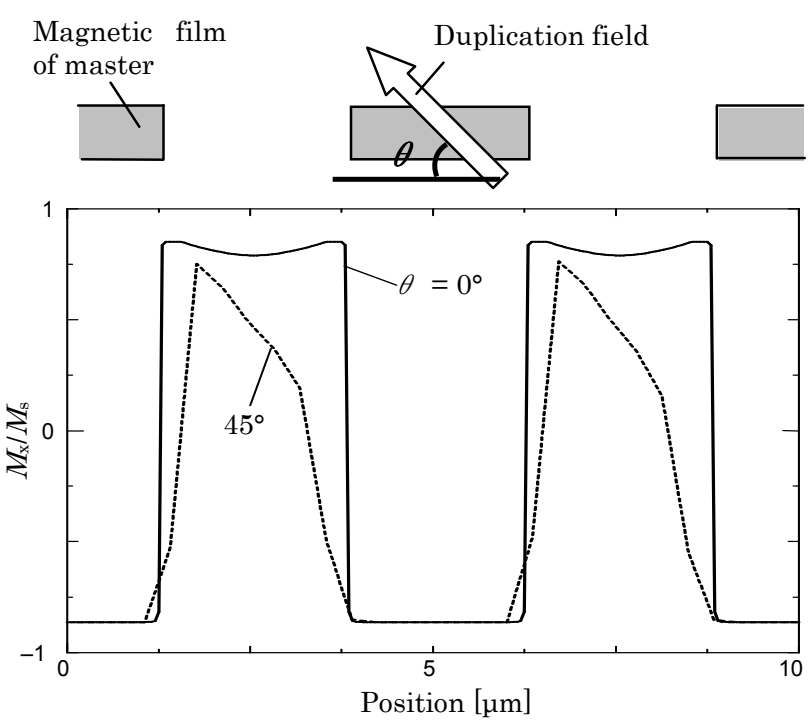

Fig. 9 Simulated magnetization distribution of slaves duplicated with $\theta$ values of $0^{\circ}$ and $45^{\circ}$.

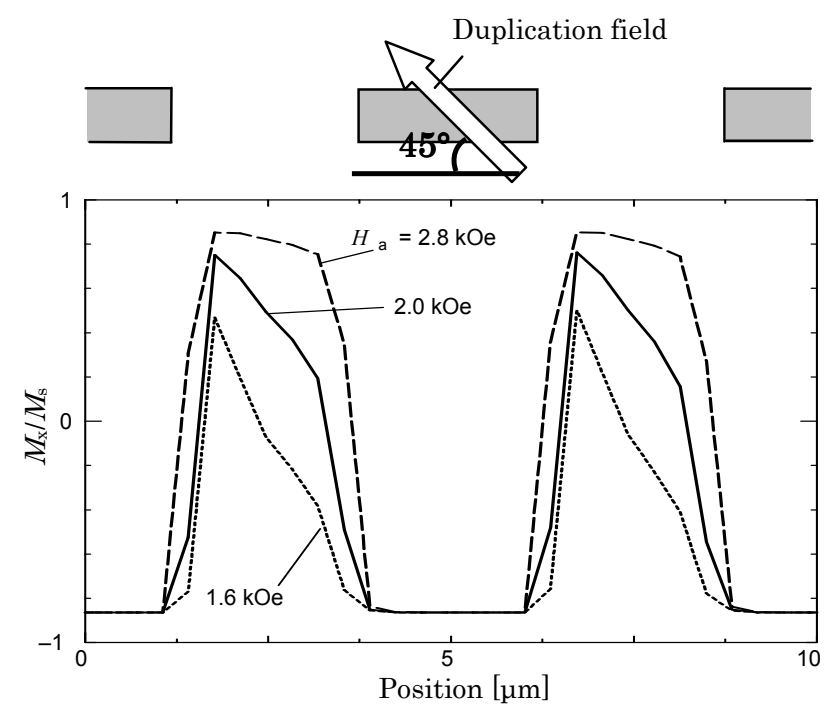

Fig. 10 Simulated magnetization distribution of slaves duplicated with a $\theta$ values of $45^{\circ}$, and with $H_{\mathrm{a}}$ values of $1.6 \mathrm{kOe}, 2.0 \mathrm{kOe}$, and $2.8 \mathrm{kOe}$.

\section{4. まとめ}

スレーブ膜面に対して, 斜め方向に印加される転写磁場 $H_{\mathrm{a}}$ が転 写特性に及ぼす影響について検討し, 次のことが明らかになった. （1）斜め方向磁場を印加して転写されたスレーブからの再生出力 波形は, マスター磁性膜両側エッジに対応する部分で非対称にな る. また, 最適転写磁場が, 面内印加の場合に比べて, 高い側にシ フトする. 斜め方向磁場を強くすると，この非対称性が緩和される が, $E_{0,+\mathrm{p}}$ と $E_{0, \mathrm{p}}$ との間に差が存在する, 半值幅が広い, サブ ピークが見られる等の点から, 水平に磁場を印加した場合の 特性には及ばない。

（2）シミュレーションを用いて，斜め方向磁場により転写され たスレーブの磁化状態を計算したところ, ピークの非対称性を説 明できる結果が得られた。

以上から, 磁石により転写磁場を印加寸る過程において, 斜め方 向成分が転写特性を劣化させることが明らかになった. また, 転写 磁場が斜め方向磁場の場合, スレーブの膜面内方向成分が $2.0 \mathrm{kOe}$ となる強度の磁場を印加することにより転写特性を改善できる.

謝辞 マスターを作製して頂いた富士写真フイルム侏に深謝致し ます. また, 本研究の一部は, 日本学術振興会平成 17 年度科学研究 費(基盤研究 C16560291)及びNEDO 産業技術研究助成事業の支援 により行われました。

\section{References}

1) R. Sugita, O. Saito, T. Muranoi, M. Nishikawa and M. Nagao, J. Appl. Phys., 91, 8694 (2002).

2) R. Sugita, T. Kinoshita, T. Muranoi, M. Nishikawa and M. Nagao, IEEE Trans. Magn., 36, 2285 (2000).

3) A. Saito, E. Yonezawa, Y. Takano, and T. Watanabe, J. Appl. Phys., 91, 8688 (2002).

4) R. Sugita, O. Saito, Y.Nakamura, T. Muranoi, M. Nishikawa and M. Nagao, J. Magn. Soc. Japan., 25, 289 (2001).

5) R. Sugita, O. Saito, T. Muranoi, M. Nishikawa and M. Nagao, J. Magn. Soc. Japan., 26, 289 (2002).

6) T. Ishida, K. Miyata, N. Komura, and T. Takeoka, IEEE Trans. Magn., 37, 1412 (2001).

7) R. Sugita, T.Komine, T. Muranoi, M. Nishikawa, T.Yasunaga and M. Nagao, J. Magn. Soc. Japan., 28, 231 (2004).

2005年10月19日受理，2005年12月15日再受理，2006年1月16日採録 